\title{
The Institutional Catholic ChuRCh in Poland ON EUROPEAN INTEGRATION
}

\author{
LUKASZ MACHAJ*, KLAUDYNA BIALAS-ZIELIŃSKA **
}

\section{INTRODUCTION}

After the fall of the communist regime, and even before that, representatives of the institutional Catholic Church in Poland have followed the process of European integration, lasting since the mid-twentieth century, with careful attention. Generally speaking, the hierarchs have assumed that the very idea of integration is in line with the principles of Catholic social teaching when considering that regional cooperation between nations is one of the stages of improvement in social life and, at least partly, a natural historical process ${ }^{1}$. Before 1989, the bishops supported this idea (as much as it was possible in that time) because they were aware that contact with Western civilization could facilitate Poland's return to "normality' after throwing off the shackles of communism ${ }^{2}$. However, immediately after the events of 1989, the issue of integration was not officially at the center of their interest. In the first half of the 1990s there were only a few general and equivocal references to this subject in some documents of the Polish Episcopal Conference (PEC) $)^{3}$, which makes it unfeasible to fully and precisely identify the position at that time of the Episcopate on European integration. The probable reason for this state of affairs was that Poland's accession to the EU seemed quite a remote prospect then. Besides, the institutional Church focused its attention at that time on matters involving domestic policy (for example, the new Constitution, the Concordat, abortion

DOI: $10.2478 /$ wrlae-2013-0001

* Assistant Professor; University of Wrocław, Faculty of Law, Administration and Economics, Department of Political and Legal Thought; 1.machaj@prawo.uni.wroc.pl

** PhD candidate; University of Wrocław, Faculty of Law, Administration and Economics, Department of Political and Legal Thought; k.bialas-zielinska@prawo.uni.wroc.pl

${ }^{1}$ Czesław Strzeszewski, Katolicka nauka społeczna (Wydawnictwo KUL 1994) 544, 556.

2 Andrzej Podraza, 'Kościół wobec procesów integracji Polski z Unią Europejską' in Piotr Dobrowolski and Mieczysław Stolarczyk (eds), Proces integracji Polski z Unia Europejska (Wydawnictwo Uniwersytetu Śląskiego 2001) 539.

3 'List Biskupów Polskich na Niedzielę Świętej Rodziny' (1990) 12 L'Osservatore Romano 23; 'Słowo biskupów diecezjalnych do wiernych w Polsce' (1991) 1-2 L'Osservatore Romano 57; 'List Episkopatu Polski o roli Katolików w procesie przekształceń polskiego rolnictwa i przeobrażeń społecznych wsi i małych miast' (1995) 2 Społeczeństwo 363-368; 'Droga w trzecie tysiąclecie. Wspólne słowo polskich i niemieckich Biskupów z okazji 30. rocznicy wymiany listów (1965-1995)‘ (1995) 52-53 Tygodnik Powszechny 9. 
regulations) which seemed more significant from the standpoint of Catholic social teaching. We can therefore conclude that directly after the political transformation, the institutional Church adopted the position of neutral observer as far as European integration and Poland's membership in the EU was concerned, being unwilling to engage in political debates and activities whose results remained quite unpredictable.

\section{I.}

The breakthrough moment in many hierarchs' approach to continental integration came undoubtedly in 1997, when the European Commission and the Commission of the Bishops' Conferences of the European Community (COMECE) ${ }^{4}$ extended an invitation to the delegates of the Polish Episcopate for an informative visit to Brussels. The trip was not political in character; the bishops went there in order to get acquainted with the modus operandi of the $\mathrm{EU}^{5}$. Nevertheless, the talks between Church hierarchs and EU representatives that took place in the Belgian capital opened a line of dialogue and helped dispel the numerous doubts held by many bishops relating to ethical aspects of EU policies ${ }^{6}$. According to Bishop Tadeusz Pieronek, the trip changed the hierarchs' attitude towards European integration ${ }^{7}$ and constituted proof that 'the Union appreciates the role of the Church in Poland, understanding that it is a powerful social force $^{\prime 8}$. Archbishop Henryk Muszyński emphasized that after the visit to the European institutions there 'came a time for creating mutual trust', and that the trip to Brussels would exert an important influence on pastoral programs concerning European integration ${ }^{9}$. Based on such statements by the Polish hierarchs-delegates, the trip may be considered as a crucial factor in shaping the Church's perception of the EU ${ }^{10}$. Nevertheless, it has to be said that that

\footnotetext{
${ }^{4}$ It should be noted that since 1998 (after informative visit to Brussels), the Polish Church has been involved in the activity of COMECE. In 1998-2004 Archbishop Henryk Muszyński served as the Delegate of the Polish Episcopal Conference for relations with COMECE. He was succeeded by Bishop Piotr Jarecki, who was first a member, and then from 2006 to 2012 a vice-president of COMECE. After his resignation, the function was taken over by Bishop Janusz Stepnowski, http://comece.org/site/en/activities/plenaryassemblies/2012/article/ 4669.html, http://comece.org/site/en/whoweare/memberbishops (accessed on 31 July 2013).

${ }_{5}^{5}$ Maciej Drzonek, Między integracją a europeizacją. Kościół katolicki w Polsce wobec Unii Europejskiej w latach 1997-2003 (Księgarnia Akademicka 2006) 44; see also Stanisław Rabiej, 'Biskupi wobec integracji europejskiej' in Ewa Kozerska and Tomasz Scheffler (eds), Aksjologiczne i praktyczne aspekty integracji europejskiej (Wydawnictwo Uniwersytetu Wrocławskiego 2007) 67.

${ }^{6}$ Ewa Czaczkowska, 'Bez obaw do Unii’ Rzeczpospolita (Warsaw, 8 November 1997) 3.

${ }^{7}$ Krzysztof Brunetko and Janusz Poniewierski, 'Twarze Kościoła. Rozmowa z biskupem Tadeuszem Pieronkiem' (1998) 23 Tygodnik Powszechny 5.

${ }^{8}$ Milena Kindziuk, 'Z wartościami do Europy’ (1997) 46 Gość Niedzielny 5.

9 jgk, mp, 'Kościół a Unia Europejska. Wizyta delegacji Episkopatu w Brukseli' (1997) 45 Biuletyn KAI 5.

${ }^{10}$ Opinions polls show that directly after the trip to Brussels $84 \%$ of Polish priests declared that they would vote 'yes' in a referendum on Poland's accession to the EU. However, an argument can be made that such enthusiastic support was fleeting, see further Maciej Drzonek, 'Entuzjazm czy sceptycyzm? Kościół katolicki i integracja europejska' in Bogumił Grott (ed) Religia i polityka (Wydawnictwo Uniwersytetu Jagiellońskiego 2000)
} 
the approving attitude displayed by the delegation's members (and many other bishops) was by no means universal. Some hierarchs, particularly those who had earlier opposed Poland's accession and had strongly criticized the current shape of Western civilization, certainly remained unconvinced. This did not stop many media outlets from interpreting the Brussels 'pilgrimage' and its results as an expression of the institutional Church's unequivocal support for the European integration project ${ }^{11}$. Probably in order to avoid internal tensions and fostering of the media's misperception of the existence of a consensus on the issue among bishops, the PEC did not immediately follow the Brussels trip with a comprehensive statement on European integration ${ }^{12}$. The absence of such an official document did not, of course, mean that the topic was utterly ignored during PEC gatherings. As the Episcopate's spokesman confirmed, the issue of European integration was the subject of many discussions during plenary meetings ${ }^{13}$. However, the time for taking an official stand did not come until 2002.

By the end of 2001 it became obvious that accession negotiations between Poland and the European Union were quickly drawing to a close. The Polish institutional Church could hardly avoid confronting this fundamental question head-on any longer. The first comprehensive communique of the PEC pertaining to this problem, 'The Polish bishops on European integration', was issued in March 2002 (after another visit of a few hierarchs in Brussels ${ }^{14}$ ). Polish churchmen stressed in the document that Europe is not just an economic or political structure, but should be perceived as 'a community of history, culture, ideas and tradition, based on permanent Judeo-Christian values, on Roman law, on Greek philosophy.' The document stated that the Church had made a large contribution to the

330-331; Kazimierz Ryczan, 'Kościół polski wobec Unii Europejskiej’ in Józef Kupny and Marek Stępniak (eds) Kościól w Europie wobec wyzwań integracji. Refleksje nad adhortacja apostolska Ecclesia in Europa Jana Pawła II (Księgarnia Świętego Jacka 2005) 17-19; Alicja Wysocka, 'Bilans zysków i strat' (1998) 17 Gość Niedzielny 10.

${ }^{11}$ See Mikołaj Lizut and Małgorzata Alterman, 'Biskupi w Europie' Gazeta Wyborcza (Warsaw, 5 November 1997) 7; Stanisław Tkocz, 'Biskupi w Brukseli' (1997) 47 Gość Niedzielny 5; Ewa Czaczkowska, 'Biskupi jednogłośnie za Unią' Rzeczpospolita (Warsaw, 29 November 1997) 3; Tomasz Wiścicki, ‘Biskupi w Unii Europejskiej’ (1997) 12 Więź 9. 10 .

12 Until 2002, official PEC documents contained only some brief, enigmatic and, quite frankly, obscure declarations referring to the subject, see e.g. II Polski Synod Plenarny (1991-1999) (Pallottinum 2001) 95-96; see also Adam Lempa, 'Dusza jednoczącej się Europy wyzwaniem dla Kościoła’ in Stanisław Urbański (ed), Chrześcijańska Europa. Wyktady wygloszone $w$ Studium Duchowości Europejskiej przy Centrum Kultury Katolickiego Stowarzyszenia 'Civitas Christiana' w latach 1999-2002 (Pax 2003) 111-115.

13 Tomasz Gołąb, 'Odkryć duchowe korzenie Europy. Rozmowa z ojcem Adamem Schulzem, rzecznikiem Konferencji Episkopatu Polski’, (2000) 20 Gość Niedzielny 5.

14 They participated in a seminar, organized under the aegis of COMECE, which dealt with EU agricultural policy and the state of accession negotiations with states applying for membership. Although the delegates remained cautious about the perspectives of the Polish agricultural sector after accession, the visit appeared to confirm in their minds that the EU is open to dialogue with the Church and counts on its support during accession's finalization, see Krzysztof Tomasik, 'Biskupi polscy w Brukseli', (2002) 7 Wiadomości KAI 20-21; see also Jędrzej Bielecki, 'Komisja Europejska liczy na pomoc biskupów' Rzeczpospolita (Warsaw, 5 February 2002) 3. 
development of European civilization and that it can continue in modern times to play a major role in the integration process, particularly by defending the fundamental moral principles contained in the Decalogue. The communiqué also referred to some of the fears of the hierarchs connected with the continent's growing secularization. It indicated that this process may easily lead to 'the dissemination of the kind of lifestyle as if there was no God', and though it is not directly connected to EU institutions, it nevertheless 'remains closely linked with the materialistic and secularized lifestyle that is promoted and fostered' in Western Europe ${ }^{15}$. The bishops also addressed the issue of Poland's accession to EU structures and warned that 'it cannot entail the renunciation of national, political and cultural sovereignty, and also of religious identity'. They appealed directly to Polish authorities to ensure that the cost of economic adjustments and reforms associated with accession would be borne proportionately and would not burden the poorest members of society. The hierarchs also emphasized the need for cooperation among the Church, the government, non-governmental organizations and EU institutions in order to prepare Poland for admission to the European Union, the need for vigorous and widespread debate on issues related to accession, and the need for providing society with reliable information on relevant matters (a step that could allay many unsubstantiated fears) ${ }^{16}$.

It is not surprising that the document elicited a lot of comments, mostly approving ${ }^{17}$. Father Bogusław Trzeciak, director of the Catholic Bureau of European Information and Initiatives, maintained that the document was 'a compendium' of the Polish Church's positions on accession which served as a good example of 'the Christian spirit of dialogue', while taking into account 'all anxieties, reservations and problems, particularly those involving our national identity' 18 . In Bishop Pieronek's opinion, the communiqué was an 'appeal to the Church in Poland to meet the serious challenge that contemporary European society poses to Christianity'. The hierarch emphasized that the document was an objective one, because it mentioned some potential disadvantages of accession and criticized certain aspects of contemporary European culture ${ }^{19}$. Bishop Józef Michalik observed that the document was 'the fruit of tumultuous but honest debates between hierarchs and it was written not as a

\footnotetext{
${ }^{15}$ It appears that at least since the 1997 Brussels visit the majority of bishops realized that the secularization of Europe is largely independent of any EU activities, and that the rejection of the integration paradigm would hardly a restore religious dimension to continental social life and certainly would not eliminate 'the ills of modern civilization', Roman Kochnowski, 'Stanowisko Kościoła rzymskokatolickiego w Rzeczpospolitej Polskiej wobec Unii Europejskiej’ in Dobrowolski and Stolarczyk (n 2) 565.

16 'Biskupi Polscy wobec integracji europejskiej' (2002) 7 Akta Konferencji Episkopatu Polski 33-36.

17 There were obviously some critical assessments (see e.g. Krzysztof Zuba, Polski eurosceptycyzm $i$ eurorealizm (Wydawnictwo UO 2006) 253, where the Episcopate is accused of 'adopting a malcontent's attitude' where continental integration is concerned) but they remained in the minority.

18 'O. Trzeciak SI: dokument biskupów o UE jest ważny, bo odrzuca skrajne opinie' (2002) 13-14 Wiadomości KAI 8.

19 Tadeusz Pieronek, 'Integracja europejska jako wyzwanie dla chrześcijaństwa' in Rafał Budnik and Michał Góra (eds), Modernizacja $i$ wiara. Rola Kościoła Katolickiego w procesie integracji europejskiej (Wokół Nas 2002) 11.
} 
negative act but as a candid and honest appraisal' that points out the obviousness and value of integration, but that does not unfoundedly belittle certain dangers which may result from accession. The churchman claimed that the Episcopate had been correct in verbalizing certain fears and, while generally accepting integration, in stressing the need for a proper accession process which would include debate, information and awareness of costs and benefits ${ }^{20}$. According to prominent Catholic journalist Jacek Woźniakowski, the document was 'concise, crystal and clear'. He claimed that the communique provided grounds to assume that the Episcopate supports Poland's entrance into the EU. The journalist stated that while the bishops realized that 'the process of social maturation' to the accession project would be long and difficult and would entail some costs, they nevertheless looked to the future with realism and optimism. Woźniakowski also expressed hope that the language of the document (thoughtful and judicious argumentation) would become the language of communication between advocates and opponents of integration ${ }^{21}$. Another journalist, Rafal Zakrzewski, saw the communiqué as 'important and joyous news'. In his opinion, the bishops approached the integration process with prudence, articulating the necessity of certain sacrifices, but at the same time accepting the general objective ${ }^{22}$. Tadeusz Mazowiecki saw the document as a 'sui generis guidepost that indicates what we - as Christians - should strive to achieve in the EU'. The former Prime Minister wrote that the reservations mentioned in the document should be interpreted as postulates for the European Union; they do not, however, constitute reasons for rejecting accession $^{23}$. All in all, Marek Bielecki is substantially correct when he claims that, although the bishops did not expressly call for voting in favour of Poland's admission to the EU in the referendum, the intentions of the PEC were clear: integration and accession was given an official [though certainly conditional - Ł.M. and K. B-Z.] seal of approval by the institutional Catholic Church in Poland ${ }^{24}$.

The Episcopate again addressed the matter of accession just before the referendum, though for a long time it was not clear that such an official statement would ever be issued. Eventually, after the $322^{\text {nd }}$ plenary gathering of the PEC had concluded, the pastoral view on the question of Poland's entrance to the EU was published. The letter was read in Polish churches on June $1^{\text {st }}$ (a week before the voting). The bishops contended that participation in the accession referendum constituted a civic duty. They also adduced the teaching of John Paul II who, in their opinion, clearly approved of Poland's inclusion in European institutions, and stated that 'all people of goodwill should seriously consider the voice of the Pope while making their choices $^{25}$. The hierarchs also indicated that all Poles who felt responsibility

\footnotetext{
${ }^{20}$ Józef Michalik, 'Minął tydzień' (2002) 14 Niedziela 7.

${ }^{21}$ Jacek Woźniakowski, 'Eurorozsądek Episkopatu’ (2002) 13 Tygodnik Powszechny 9.

${ }^{22}$ Rafał Zakrzewski, 'Siła wątpienia' Gazeta Wyborcza (Warsaw, 22 March 2002) 4.

${ }^{23}$ Tadeusz Mazowiecki, ‘Europa, jakiej chcemy’ (2002) 8-9 Więź 47-48.

24 Marek Bielecki, 'Stosunek Kościoła katolickiego do Unii Europejskiej' in Waldemar Bednaruk et al. (eds), Unia Europejska 2009/2010. Aksjologia, prawo, gospodarka $i$ ochrona środowiska (Wydawnictwo KUL 2010) 59-60.

${ }^{25}$ It is worth mentioning that, for example, on 19 May 2003, in a speech to participants in the National Pilgrimage to Rome, John Paul II observed that 'Poland has always been an important part of Europe and it should not exclude itself from this community today [...]
} 
for the country should rise above all divisions and, 'on an issue of such importance as Poland's entrance to the EU', should express their will in a way conducive to the common good ${ }^{26}$. Nevertheless the document did not contain an unequivocal approval of accession. The hierarchs seemed to think that by including references to the Pope's position they could communicate their views without openly stating their preferences (in a sort of a 'wink-wink, nudge-nudge' manner). The political polarization among Catholics on the relevant issue was an obvious and understandable reason for this modus operandi. The bishops faced a dilemma: either to adopt a clear position and risk alienating many of the faithful or to prevaricate. Besides, the Episcopate itself was also not unanimous ${ }^{27}$. All in all, while the institutional Church's vacillation may have been frustrating for enthusiasts of integration, the sociopolitical reality and internal divisions precluded granting accession more direct support (though the general undertone of the document was easy to comprehend $)^{28}$.

The year of the referendum was very important to the European community, and not just because of EU enlargement. In 2003 the draft of a European Constitution reforming the Union's structure was being prepared. The content of the future Constitutional Treaty evoked strong emotions in Poland. In February the first draft of the Constitution was presented, which greatly disturbed the representatives of the Episcopate ${ }^{29}$. In its August

The accession of our country and of our brotherly Slavic nations to the structures of European Union, with rights equal to other states, is an act of certain historic justice and, on the other hand, may constitute an enrichment of Europe. Europe needs Poland and Poland needs Europe', Jan Paweł II, 'Przemówienie do uczestników Narodowej Pielgrzymki do Rzymu', (2003) 7-8 L'Osservatore Romano 44-47. Some commentators contrasted the Pope's clear approach to the issue with the Polish Episcopate's alleged ambiguity, equivocality and prevarication on the topic, see e.g. Marek Zając, 'W jedności podzieleni' (2003) 25 Tygodnik Powszechny 10. For a refutation of such criticism see Michał Okoński, 'Unijne pastwiska. Rozmowa z ks. Bogusławem Trzeciakiem ekspertem ds. integracji' (2003) 23 Tygodnik Powszechny 2.

${ }^{26}$ It should be recalled that the validity of the referendum depended on voter turnout exceeding $50 \%$; therefore some opponents of accession promoted boycotting the vote. See Ewa Czaczkowska, 'Drogowskazem nauczanie papieża' Rzeczpospolita (Warsaw, 5 May 2003) 5 .

${ }^{27}$ Marek Zając, 'Quo vadis? Do Europy!' (2003) 12 Tygodnik Powszechny, 12/2003 18. Bishop Pieronek revealed that the contents of the pastoral letter were the result of compromise and voting, Marek Zając, Kościół bez znieczulenia. Rozmowa z biskupem Tadeuszem Pieronkiem (Znak 2004) 211-212.

${ }^{28}$ After accession was accepted by popular vote, the PEC concluded that 'as a result of the referendum, Polish citizens undertook the responsibility for furthering the process of building European unity not only in political and economic matters but, first and foremost, in the spiritual and cultural dimension. Our presence in the European Union will be a test of Polish patriotism and a test of the depth of our faith and culture. Our presence in a united Europe is not an end in itself. It is supposed to serve as a means to an end, which is the creation of conditions that are most suitable for every human being's full development', Komunikat z 323. Zebrania plenarnego Konferencji Episkopatu Polski' (2004) 1 Akta Konferencji Episkopatu Polski 58-59.

${ }^{29}$ The bishops first raised the subject of the European constitution in a communiqué issued in March 2002. In their opinion, the future constitution should clearly delineate the purposes and values underlining cooperation between EU members; it should guarantee every person's right to life from conception until natural death; it should define marriage as a union between man and woman. They also criticized the Charter of Fundamental Rights, criticizing the fact that any direct references to religion (and, by extension, Christianity) had 
communiqué the Permanent Council of Episcopate and Diocesan Bishops, once again recalling the exhortations of John Paul II, demanded 'taking into account the historical experiences of both our country and the whole of Europe, and searching for ways out of a moral crisis and out of our continent's social, political and economic difficulties', the inclusion of Invocatio Dei in the Reform Treaty, and the recognition of the fundamental role played by Christianity in Europe's development ${ }^{30}$. The hierarchs issued a similar appeal in September in a letter addressed to Italian Prime Minister Silvio Berlusconi ${ }^{31}$. The bishops observed that since the European Constitution was supposed to determine the united continent's future, it could not disregard Europe's spiritual foundations. The hierarchs insisted that the Treaty take into account Europe's Christian legacy and include reference to the European religious heritage ${ }^{32}$. The topic of Invocatio Dei was also raised during the August gathering of the PEC. The bishops expressed their disapproval of not only the fact that the Treaty's preamble avoided making reference to God as a source of European identity, but also of the lack of sufficient regard given in the document to the principles of Catholic social teaching - such as solidarity, subsidiarity ${ }^{33}$ and fraternity which should serve as a cornerstone of European integration, particularly with respect to cooperation between EU institutions and relevant national structures and to the vision of natural human relations which ought to be embodied in the proposed Constitution.

In March 2004 ${ }^{34}$, in connection with the approaching completion of the accession process, the Episcopate published two documents linked with Poland's admission to the European Union: 'Christian Responsibility for the Country. The Appeal of Polish Bishops for Responsibility for the Future of Poland and Europe in the Face of Poland's Accession to European Union Structures' and 'The Word of the Polish Bishops on the Occasion of Poland's Admission to the European Union'. The first document contended that the positive decision on accession creates an obligation 'to use this historical moment for the good of the nation, accept newly-emerging challenges and steadfastly resist any dangers that may flow' from our participation in the European Union. According to the bishops, the gravest

\footnotetext{
been removed from its preamble, Biskupi Polscy wobec integracji europejskiej (n 16) 35. The topic was also raised during the $318^{\text {th }}$ plenary gathering of PEC. After the meeting, the General Secretary of PEC stressed that the hierarchs 'cannot imagine that a future European constitution would not include reference to God,' and that Polish bishops would not accept a European project that marginalized 'Christian heritage' and discriminated against believers, 'Z obrad Konferencji Episkopatu Polski’ (2002) 25 Niedziela 15.

30 'Słowo Rady Stałej Konferencji Episkopatu Polski oraz Biskupów Diecezjalnych' (2003) 36 Gość Niedzielny 7.

${ }^{31} \mathrm{He}$ was the addressee because Italy held the EU Presidency at the time.

32 'List Prezydium Konferencji Episkopatu Polski do Premiera Silvio Berlusconiego o projekcie Traktatu Konstytucyjnego Unii Europejskiej' (2004) 1 Akta Konferencji Episkopatu Polski 19.

${ }^{33}$ For a more in-depth criticism from a Catholic perspective of the Treaty's stance on subsidiarity see Krzysztof Mądel, 'Nowa Konstytucja Europejska w świetle katolickiej nauki społecznej' (2003) 9 Biuletyn OCIPE 7.

${ }^{34}$ It should be noted that at the same time the election of the new Chairman of PEC took place. The clearly pro-integration Primate Józef Glemp was replaced by Archbishop Józef Michalik, who was evidently more skeptical as far as European integration was concerned.
} 
peril is brought about by the growing secularization of Europe. This process is reflected in and exemplified by the text of the proposed Constitution Treaty, whose preamble omits any reference to God. The Polish Episcopal Conference observed that

'it is paradoxical that the attitude of openness is being declared while simultaneously God and religious values are being eliminated. For its part the Church fully recognizes and acknowledges the autonomy, independence and secular character of public and governmental institutions; however, the principle of secularity cannot, under any circumstance, be confused with an ideology of laicization.'.

The bishops suggested in this context that Polish society should resist certain Western influences and openly oppose the growing disrespect for the religious dimension of public life, also visible in EU structures ${ }^{35}$. In the latter document, the hierarchs emphasized that 'the development of Europe demands building a civilization of life and love'. They indicated many dangers which may be - and often are - caused by the expansion of the laicization of life in the Western part of Europe. In the hierarchs' opinion, 'not just Catholics, but nobody who appreciates humanist and universal values can participate in shaping public opinion in such a way as to persuade others to be favorably disposed towards attempts on human life'. In the document the Episcopate very strongly objected against genetic manipulations, legalization of abortion, euthanasia and so-called 'civil partnerships' (the legalization of which supposedly strikes at the very foundations of marriage and family) $)^{36}$. In both documents issued 'on the occasion of Poland's admission to the European Union' the concern of the Church's representatives for preservation of the most fundamental Christian values in the European community is clearly distinguishable. The bishops were obviously convinced that these values should provide a basis or stepping-stone for further international cooperation in Europe. While the hierarchs explicitly contended that deference to these values would enrich the European community, they also focused on one particular issue of the inclusion of Invocatio Dei in the preamble to the Constitutional Treaty. It seems that this issue was of huge symbolic significance for the bishops; they

\footnotetext{
35 'Słowo biskupów polskich z okazji przyjęcia Polski do Unii Europejskiej' (2004) 1 Akta Konferencji Episkopatu Polski 39-43. See also Adam Boniecki, 'Lada moment w Unii' (2004) 17 Tygodnik Powszechny 2. According to him (and we tend to agree), it should be noted that this letter from the Polish bishops reads like a compromissory statement. While the more traditionalist wing of the Episcopate should have been satisfied with the aforementioned criticism of the contemporary laicization of European societies, the document also perceived religious pluralism and tolerance as correct and normal principles and accepted references to religions other than Catholicism in the future preamble of the modified European Constitution.

36 'Chrześcijańska odpowiedzialność za ojczyznę, Apel biskupów polskich o odpowiedzialność za przyszłość Polski i Europy w obliczu wstąpienia Polski do struktur Unii Europejskiej' (2004) 5 L'Osservatore Romano 55-57; In the document the Church representatives also called on citizens to participate in the first election of Polish members of the European Parliament (as an expression of responsibility for the country and for its worthy place in the uniting Europe). It is interesting and perhaps significant that the bishops did not just appeal to take part in the voting, but also to choose candidates who would act not only for the good of Poland or Europe, but also for the good of the Church, see 'Głos biskupów przed wstąpieniem Polski w struktury UE’ (2004) 17 Niedziela 10.
} 
appeared to identify the absence of references to God and Europe's Christian heritage with the absolute elimination of religion from the public sphere $^{37}$. The importance attached by the bishops to this issue is confirmed by the fact that they returned to it once again in May during the $327^{\text {th }}$ gathering of the PEC (in connection with the EU summit planned for June 2004 and devoted to constitutional discussions, especially with respect to the preamble). They published another letter (this time addressed to Prime Minister of Ireland Bertie Ahern) requesting that all EU governments and parliaments try to secure the inclusion of Invocatio Dei in the future constitution. In the hierarchs' opinion, it would be a gross historical injustice and falsification not to take into account the centuries-long influence of Christianity on the shape of the European continent's development ${ }^{38}$.

The critical voices of many (by no means only Polish) representatives of the Catholic Church notwithstanding, the final text of the Constitutional Treaty (agreed in June 2004) did not expressly mention the Christian roots of European civilization, nor did it include Invocatio Dei. The ultimate version of the Constitution referred only to 'the cultural, religious and humanist inheritance of Europe, from which have developed the universal values of the inviolable and inalienable rights of the human person, freedom, democracy, equality and the rule of law'; the meaning of the term 'religious' was not specified. The Polish Episcopate quickly expressed its outrage at such a turn of events and did not mince words. The Presidium of PEC condemned the aforementioned omissions, contending that they were a falsification of historical truth and the result of 'conscious marginalization of Christianity, which for centuries was - and still is - the religion of a significant majority of Europeans'. According to the bishops, Europe cannot be built on such deceptions, nor by imposing a secular perspective or outlook on societies ${ }^{39}$. It seems safe to assume that the subsequent rejection of the treaty in referendums in France and the Netherlands did not particularly worry Polish hierarchs, but we will return to this point in a more detailed manner shortly.

Another contentious issue in the integration discourse came to the fore because of the debate started by the European Parliament on the problem of discrimination and spreading of hate acts in Europe on the basis of sexual orientation. The European Parliament published a relevant resolution on homophobia in Europe on 18 January $2006^{40}$. The document stated that

'a series of worrying events has recently taken place in a number of Member States $[\ldots]$ ranging from banning gay pride or equality marches to the use by leading politicians and religious leaders of inflammatory or threatening language or hate speech, failure by police to provide adequate

\footnotetext{
${ }^{37}$ See further Józef Tischner, 'Droga do europejskiej nowożytności’ (2003) 6 Tygodnik Powszechny 10.

38 'List Biskupów Polskich do Premiera Irlandii' (2004) 1 Akta Konferencji Episkopatu Polski 55.

39 'Oświadczenie Prezydium KEP w sprawie przyjętego Traktatu Konstytucyjnego' (2004) 1 Akta Konferencji Episkopatu Polski 57.

40 The text can be found at http://www.europarl.europa.eu/sides/getDoc.do?pubRef=//EP//TEXT+TA+P6-TA-2006-0018+0+DOC+XML+V0//EN (accessed on 30 July 2012).
} 
protection or even breaking up peaceful demonstrations, violent demonstrations by homophobic groups, and the introduction of changes to constitutions explicitly to prohibit same-sex unions'.

The European Parliament called on 'Member States to ensure that LGBT people are protected from homophobic hate speech and violence and ensure that same-sex partners enjoy the same respect, dignity and protection as the rest of society', condemned 'any discrimination on the basis of sexual orientation' and urged Member States and the European Commission to 'condemn homophobic hate speech or incitement to hatred and violence, and to ensure that freedom of demonstration - guaranteed by all human rights treaties - is respected in practice' and to 'step up the fight against homophobia through education, such as campaigns against homophobia in schools, in universities and in the media, as well as through administrative, judicial and legislative means'. The Parliament also advocated undertaking certain legislative measures designed to achieve these objectives on the European level, thus forcing member states to effectively apply the resolution in practice ${ }^{41}$. It is hardly surprising that the document was not favorably received by Polish bishops, both personally ${ }^{42}$ and institutionally. During the $334^{\text {th }}$ plenary gathering of the Polish Episcopal Conference the resolution was roundly criticized for endangering 'both the concept of the family and the concept of the human being. Even thought it is not legally binding for member states, it still exerts moral pressure on the EU countries and it constitutes a betrayal of the most fundamental values of our civilization'43. In 2009, the Episcopate's Council on the Family also addressed the resolution. It declared in a lengthy statement that there were pressures in Europe 'both on the ideological and legislative levels', the aim of which is 'to destroy traditional marriage and the family, which provide a foundation supporting our civilization'. One especially vivid example of such efforts is the growing pressure to put marriage and civil unions on equal legal footing, exemplified by an alleged attempt to remove the terms 'father' and 'mother' from public language in order not to discriminate against 'minority unions' by imposing a heterosexual model of family. The Council claimed that, often under the guise of 'human rights', 'freedom' and 'tolerance', Christians were being forced to behave in a manner contrary to their religious principles which - it was underlined once again - were the bedrock of Western civilization ${ }^{44}$.

\footnotetext{
${ }^{41}$ See also Dominika Pszczółkowska, 'Parlament Europejski przyjął rezolucję przeciwko homofobii' Gazeta Wyborcza (Warsaw, 19 January 2006) 7

${ }^{42}$ For instance, Archbishop Józef Życiński claimed that the resolution was an attempt to interfere with Polish consciences and tried to exert influence on personal moral convictions by administrative means. According to Życiński, one particularly unacceptable feature of the document is a call for EU member states to revise their legislation concerning same-sex unions. He expressly maintained that 'such appeals violate the principles of social life in Europe' '334. Zebranie plenarne Konferencji Episkopatu Polski' (2006) 6 Wiadomości KAI 5.

43 'Oświadczenie Konferencji Episkopatu Polski w sprawie rezolucji Parlamentu Europejskiego dotyczącej homofobii' (2006) 1 Akta Konferencji Episkopatu Polski 97-98.

44 'Służyć prawdzie o małżeństwie i rodzinie' Dokument Konferencji Episkopatu Polski przygotowany przez Rade ds. Rodziny (2009) 15 Akta Konferencji Episkopatu Polski 62 63.
} 
The European Parliament did not confine its activities to accepting controversial resolutions. On 18 December 2006, the final decision (982/2006/EC) of the European Parliament and of the Council concerning the Seventh Framework Programme of the European Community for research, technological development and demonstration activities was issued $^{45}$. The document approved of financing by the European Union of research on human stem cells, both adult and embryonic. This type of scientific endeavor directly collided with the Catholic Church's doctrine on the sanctity and protection of human life. While obviously no Member States were obliged to undertake such research, they were supposed to contribute financially to research conducted in countries where such studies were permitted (such as in Great Britain, Spain, France, Belgium or the Netherlands). It should be added that the relevant decision excluded three fields of research from financing:

- research activities aiming at human cloning for reproductive purposes;

- research activities intended to modify the genetic heritage of human beings which could make such changes inheritable;

- research activities intended to create human embryos solely for the purpose of research or for the purpose of stem cell procurement, including by means of somatic cell nuclear transfer.

From the standpoint of Polish bishops, the aforementioned exclusions were clearly not sufficient. The hierarchs still believed that the decision constituted very serious legislative interference with the absolutely fundamental objective of protecting human life. Their position can be best summed up by an earlier statement, issued during the $336^{\text {th }}$ plenary gathering of the PEC (23-25 June 2006) in response to the European Parliament's opinion of 15 June 2006 which advocated European financing of stem cell research. The bishops declared that they were not opposed to progress or science and that they supported the development of scientific research in the European Union. At the same time, they maintained that research on embryonic stem cells raised considerable ethical doubts because it involved the destruction of human embryos. During such research, human embryos are objectified, instrumentalized and treated as a means to an end, which violates their personal dignity. According to the PEC, forcing countries that prohibit such research to financially contribute to it constitutes an infringement of the principle of subsidiarity, in light of which the European Union should abstain from regulating controversial issues of profound ethical importance. In conclusion, the bishops used quite strong language, stating that such disregard for the fundamental value of human life 'undermines trust in the European Union and its decision-making processes $^{\text {' }}$.

\footnotetext{
45 http://eur-lex.europa.eu/LexUriServ/LexUriServ.do?uri=CELEX:32006D1982:EN:NOT (accessed on 25 July 2012).

46 'Oświadczenie biskupów zgromadzonych na 336. Zebraniu Plenarnym Konferencji Episkopatu Polski w sprawie decyzji Parlamentu Europejskiego dotyczącej finansowania badań nad embrionami ludzkimi oraz zarodkowymi komórkami macierzystymi' (2006) 12 Akta Konferencji Episkopatu Polski 82-83; see further Renata Krzyszkowska, 'Życie zduszone w zarodku' (2006) 29 Przewodnik Katolicki 42-43; im, 'Ks. prof. Mazurkiewicz: zły wzór na przyszłość' (2006) 31 Wiadomości KAI 10-11.
} 
After a yearlong hiatus (the so-called 'period of reflection'), the question of a new treaty - later, of course, to become the Lisbon Treaty comprehensively regulating the architecture and functioning of the European Union (no longer called a 'Constitution') once again came to the fore. The Polish bishops decided to participate in this discussion as well. During the $339^{\text {th }}$ plenary gathering of PEC (13-14 May 2007) the hierarchs attempted to summarize the positive and negative aspects of the Constitutional Treaty. Their communiqué stated that there were certain elements of the Treaty which deserved approval or at least acceptance. In this context they specifically mentioned Article I-52 ('The Union respects and does not prejudice the status under national law of churches and religious associations or communities in the Member States'; 'Recognising their identity and their specific contribution, the Union shall maintain an open, transparent and regular dialogue with these churches') and Article II70 (guaranteeing freedom of religion, including 'freedom, either alone or in community with others and in public or in private, to manifest religion or belief, in worship, teaching, practice and observance'). Once again, however, the hierarchs expressed their dissatisfaction with the absence of Invocatio Dei and the lack of recognition of Christianity's role in the development of the European continent in the Constitution's preamble ${ }^{47}$. It should be noted that this summation referred to a document which at that time had absolutely no hope of being adopted. Therefore the communiqué's objective was to tacitly indicate changes expected in the new Treaty by the bishops. While the Lisbon Treaty did not fulfill these expectations, it is worth noting that the Polish institutional Church did not advocate its rejection during the ratification process. We think that this stance was closely connected with the solution adopted in Poland regarding the issue of the Charter of Fundamental Rights of the European Union, which the Lisbon Treaty made legally enforceable. After the $342^{\text {nd }}$ plenary gathering of PEC the bishops published a statement evaluating the Charter. Their assessment was balanced. On the one hand, they spoke very favorably of 'attempts to institutionally secure the process of European integration by making a law which references values, particularly those of Christian origin and those, like human rights, that constitute the most precious component of the religious, moral, cultural and civic traditions of Europe', of the mention in the preamble of 'the spiritual, religious and moral heritage of Europe' and of the provisions that 'are closely linked with ethical and social principles, like the inalienable dignity of every human being, solidarity, subsidiarity and respect for national identities'. On the other hand, they criticized the Charter for not comprehensively prohibiting human cloning (with the exception of reproductive cloning), omitting Invocatio Dei and not defining marriage as a permanent union between a man and a woman ${ }^{48}$. Because of these reservations, the hierarchs approved the decision of the Polish

\footnotetext{
47 'Biskupi dostrzegli pozytywne rozstrzygnięcia, zawarte w Traktacie Konstytucyjnym, dostrzegają jednak dwa zasadnicze braki' Stanowisko Episkopatu Polski w sprawie Traktatu Konstytucyjnego Unii Europejskiej (2007) 13 Akta Konferencji Episkopatu Polski 61-62.

48 'Po zakończonych ćwiczeniach duchowych biskupi przedyskutowali kilka tematów ważnych dla Kościoła w Polsce' Komunikat z 342. Zebrania Plenarnego (2007) 13 Akta Konferencji Episkopatu Polski 69.
} 
government to sign Protocol on the Application of the Charter of Fundamental Rights of the European Union to Poland and the United Kingdom $^{49}$, which expressly stated that 'the Charter does not extend the ability of the Court of Justice of the European Union, or any court or tribunal of Poland or of the United Kingdom, to find that the laws, regulations or administrative provisions, practices or action of Poland or of the United Kingdom are inconsistent with the fundamental rights, freedoms and principles that it reaffirms'. We believe that the adoption of the Protocol - which, according to the words of the Episcopate's communiqué, guaranteed the independence of Polish legislation on moral matters - was an indispensable condition for the bishops' acceptance of - or, at the very least, absence of open protest against - the Lisbon Treaty's ratification.

\section{CONCLUSION}

After the Lisbon Treaty came into force on 1 December 2009, the public debate in Poland on European integration clearly withered, quite often becoming mired in technical details. The institutional Catholic Church in Poland itself followed this trend, perceiving Poland's membership in the reformed European Union as a fait accompli. Any references to integration issues in the documents of PEC were brief and equivocal ${ }^{50}$. The current official position of the Catholic Church in Poland on European integration ${ }^{51}$ is perhaps best summed up by Catholic journalist Marek Zając, who astutely observes that while bishops are often skeptical towards the united Europe because of its relativism, unwillingness to protect life, bureaucratic excesses and national egotism, they generally believe that 'it is far more effective to be critical as a Community member than as an applicant standing behind closed doors' 52 .

\footnotetext{
${ }^{49} \mathrm{http}: / / \mathrm{www}$. lisbon-treaty.org/wcm/the-lisbon-treaty/protocols-annexed-to-thetreaties/676-protocol-on-the-application-of-the-charter-of-fundamental-rights-of-.html (accessed on 10 July 2012).

${ }^{50}$ See for example 'W atmosferze oczekiwania na beatyfikację Jana Pawła II' Komunikat z 354. Zebrania Plenarnego Konferencji Episkopatu Polski (2011) 1 Akta Konferencji Episkopatu Polski 63-64; the document talked in very general terms about proposed goals for Poland's EU Presidency, like the promotion of religious freedom, protection of 'unborn life' or fighting the demographic crisis.

${ }^{51} \mathrm{We}$ would be remiss in not observing that many individual bishops held and expressed very specific views on the topic, ranging from distinctly pro-integration opinions to vociferously anti-integration denouncements.

${ }^{52}$ Marek Zając, 'Głosowanie na ambonie' (2009) 23 Tygodnik Powszechny 11.
} 